\title{
Perineal outcomes and its associated variables of water births versus non-water births: a cross-sectional study
}

Joyce da Costa Silveira de Camargo 1

iD https://orcid.org/0000-0001-9171-0865

Vitor Varela 2

iD https://orcid.org/0000-0003-1873-251X

Fernanda Marçal Ferreira 3

https://orcid.org/0000-0003-3383-1540

Christiane Borges do Nascimento Chofakian 4

iD https://orcid.org/0000-0002-5953-3296

Ruth Hitomi Osava 5

https://orcid.org/0000-0002-8618-5864
Natalúcia Matos Araújo 6

(iD) https://orcid.org/0000-0003-1353-6245

Nadia Narchi 7

iD https://orcid.org/0000-0003-0075-2360

Maria Elisabete Santos 8

iD https://orcid.org/0000-0002-7618-5449

Manuela Nené 9

(iD) https://orcid.org/0000-0002-4916-2663

Catarina Grande 10

iD https://orcid.org/0000-0003-4675-6279

1,4,5,6,7 School of Arts, Sciences and Humanities. University of São Paulo. Rua Arlindo Bettio, 1000. São Paulo, SP, Brazil. CEP: 03.828-000. E-mail: joyce@usp.br 2,8 São Bernardo Hospital. Setúbal, Portugal.

3 School of Nursing. University of São Paulo. São Paulo, SP, Brazil.

9 School of Health of the Portuguese Red Cross. Lisboa, Portugal

10 Faculty of Psychology and Educational Sciences. University of Porto. Porto, Portugal

\begin{abstract}
Objectives: to describe the perineal outcomes of women who had delivered in water and out of water.

Methods: a cross-sectional and quantitative study developed in a public hospital in Setúbal, Portugal. The population was of women who participated in the "Water Birth Project" in the period from 2011 to 2014, which gave birth in water and out of water. 104 women were selected according to established inclusion criteria. The groups were compared according to the following variables: demographics, obstetric information, delivery care and perineal outcomes. The data were analyzed in the Stata ${ }^{\circledR}$ software, with descriptive and bivariate statistics (chi-square and Fisher's test).

Results: the medical records of 73 women who gave birth in water and 31 women who gave birth out of water were studied. Water deliveries were significantly associated with fewer perineal lacerations, lower rates of episiotomy, and shorter delivery time.

Conclusions: the results of the study suggest that childbirth in water has a protective effect against severe third or fourth degree perineal tears, during fetal expulsion in water. Key words Episiotomy, Perineum, Natural childbirth, Parturition, Midwifery
\end{abstract}

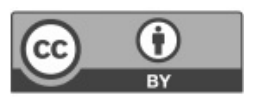




\section{Introduction}

Perineal trauma is a frequent event in women who are giving birth for the first time. ${ }^{1}$ Approximately two-thirds of these women have different varieties of laceration. ${ }^{2}$ A surgical cut in a section of the skin is called an episiotomy. Spontaneous trauma to the perineum, called laceration, has its own classification, and can range from first to fourth degrees according to the adopted classification and the damaged perineal tissue. ${ }^{2}$

The perineal trauma classification that has gained more acceptance is that of the United Kingdom Obstetrics and Gynaecology Real College, which is adopted by the National Institute for Health and Care Exceller (NICE) ${ }^{3}$ and classifies as first degree those spontaneous lacerations when the wound is limited to the skin and/or the connective tissue without any bleeding or minimal bleeding. A second-degree laceration reaches perineal muscles, preserving the anal sphincter. Severe perineal traumas are classified in third and fourth degrees. A third-degree laceration reaches the anal sphincter complex, and then it subdivides into one of three types, as follows: a) when less than $50 \%$ of the anal sphincter depth is ruptured; b) when more than 50\% of the anal sphincter depth is ruptured; and c) when the entire anal sphincter is ruptured. The fourth degree occurs when the perineal trauma reaches the rectal mucous membrane.

Normally, first- and second-degree lacerations do not demand treatment and self-heal without any sequelae. However, third- and fourth-degree traumas cause significant problems in the postpartum period, 4,5 resulting in medium- to long-term health implications, such as bowel incontinence. 5-9 The prevalence of perineal trauma depends on several factors and can be associated with foetal and maternal conditions, to a normal birth on its own, and to the episiotomy, which can have an impact more severe than the spontaneous laceration. 4,10

The episiotomy is intentionally made by the healthcare professionals typically reaches the perineal transverse superficial muscle and the bulbocavernosus muscle. This kind of perineal birthcut has been incorporated into the obstetric assistance routine in hospitals. But, in recent years, the episiotomy has started to be questioned as a routine procedure to prevent perineal trauma during a normal birth. In a review on this subject, the perineal application of hot compresses had a positive effect on the reduction of third- and fourth-degree lacerations [relative risk (RR) $0.48,95 \%$ confidence index (CI):0.28-0.84]. Based on hot compress evidence, it is possible that immersion in hot water represents a similar process. 4

Birth in water or the expelling of the newborn into water during birth typically occurs during the complete immersion of the woman's abdomen during delivery in a pool or a bathtub large enough to provide complete movement for the mother, allowing her to change position within the water. ${ }^{11}$ Therefore, the concept of childbirth in water includes underwater foetal immersion at the time of birth. 12

The first report of a water birth in medical journals appears in 1805 in France. 13,14 Odent was the second author to report on a water birth in a scientific publication, in Pithiviers, France, in the 1970s, with 100 births in a water pool of 2 meters in diameter and approximately 0.7 meters deep, at the temperature of $37^{\circ} \mathrm{C}$, in which women had freedom of movement and comfortable positioning for childbirth. 14

The Royal College of Midwives (RCM) supports delivery in water, which has been available in the UK since the 1980s. The benefits of immersion in water during labour are pain relief, freedom of movement, and the possibility of having a holistic and private experience for the woman and her partner, resulting in great maternal satisfaction with the experience of childbirth. 15

Water birth is strongly associated with the reduction of pain sensation and lower rates of epidural analgesia; however, its effects on perineal outcomes are not yet known. 11 Our study aims to describe the perineal outcomes of women who had water and non-water births. Our expectation is that women with water births have better perineal preservation than women who have non-water births.

\section{Methods}

This is a cross-sectional study that was conducted in Setúbal, Portugal, which was the only Portuguese city with a Water Birth Project (WBP) in a São Bernardo Hospital, a public institution that was totally financed by the country's National Health Service.

The population of the study was composed of women who participated in the WBP, who gave birth in water and out of water from 2011 to 2014.The inclusion criteria were the women should be part of the WBP, had low risk pregnancy, a natural childbirth and the perineal outcomes described in medical records. The exclusion criteria were instrumental deliveries.

This study adopted the concept of low-risk preg- 
nancy of the General Directorate of Health of Portugal. A low-risk pregnancy is one in which it is not possible to identify, after a clinical evaluation according to the prenatal risk assessment based on the modified Goodwin scale, no increased factor of maternal, fetal and /or neonatal health risk. ${ }^{16}$

A protocol defined by the technical-scientific team at the hospital specifically for the WBP stipulates that the women had to stay a 2-hour immersion in water during labour and different water temperature according to the stage of labour: latent phase: $37^{\circ} \mathrm{C}$; up to $8 \mathrm{~cm}$ dilation: $35^{\circ} \mathrm{C}-37^{\circ} \mathrm{C}$; expulsive phase: $33^{\circ} \mathrm{C}-35^{\circ} \mathrm{C}$; after birth: $35^{\circ} \mathrm{C}-37^{\circ} \mathrm{C}$.

All data were collected in the medical records by the midwives who assisted the births, using a specific formulary for WBP. The registration included the women's obstetrical historic, immersion characteristics, labour and birth, and maternal and neonatal outcomes. All medical record information was collected in April 2016 from all eligible participants. Ninety medical records from water births and 63 medical records from non-water births were studied. Those women who had planned a water birth but had to change to a surgical childbirth [caesarean section (c-section) or instrumental vaginal birth] were excluded. Also, data from 17 water births and 12 non-water births were excluded, due to registration failure. The medical records of 73 participants whose outcomes were water births and 31 women who had non-water births were analysed (Figure 1).

The variables investigated where: women's age, parity, labour time, weight of the newborn, perineal outcomes, birth modality (water or out of water), obstetric history and directed pulls.

For data management and storage, Microsoft Excel $^{\circledR}$ was used. All data were transferred to Stata (Stata Corporation, College Station, TX, USA), version 14.2. A statistical description was made through absolute frequencies and relative and bivariate analysis, through correlations using the Chi-square test and the Fisher exact test (95\%CI).

This research has ethical approval of the National Commission of Research Data Protection of Portugal (9885/2015 and 5145/2015) and of the Ethics Committee for Health of the São Bernardo Hospital (68/2015).

\section{Results}

A total of 104 participants from WBP were distributed according to demographic and obstetrical variables and according to the perineal outcome. Of the participants, $69,2 \%$ were more than 30 years of age.
Approximately two-thirds of the study's participants (64.4\%) were primiparas. Among all multiparas, $72.9 \%$ had only one child. Counting from the time of hospital admission, the women had a labour of less than 8 hours in $78.9 \%$ of the cases and less than 4 hours in $40.4 \%$ of the cases (Table 1 ).

Table 2 presents the proportion of women by type of childbirth (delivery in water or out of water), according to pregnancy characteristics, labour, and delivery.

Table 3 presents the proportion of women by perineal laceration degree, according to pregnancy characteristics, labour and delivery. The variables 'Delivery', 'Directed pushing' and 'Length of labour' were associated with perineal outcomes $(p<0,05)$.

\section{Discussion}

The women selected for the WBP had the same sociodemographic characteristics and similar obstetric history. The majority of women $(73,1 \%)$ had completed term gestation, that is between $390 / 7$ and $406 / 7$ weeks. In regard to this classification, our study adopted the American Association of Obstetrics and Gynecology's definition of gestational age, 17 which defines early term gestation as those between 37 completed $(0 / 7)$ and 38 weeks plus 6 days (6/7); complete term gestation as those between 39 0/7 and 40 6/7 weeks; late term gestation as those between $410 / 7$ and $416 / 7$ weeks; and postterm gestation as those of 42 weeks or more. It is important to note that there was not a statistically significant difference in gestational age between the two groups in this study.

Regarding the duration of labor, occurred significant difference between the two groups, with longer duration in the non-water delivery group, in comparison with water delivery groups. Odent 18 proposed this method, above all, to pregnant women who were had long and painful labour. In 2015, Odent 18 explained that all women who went into the pool would have immediate pain relief and reduction of stress hormones. As stress hormones and oxytocin are antagonistic, the result would be, within a short time, a peak in oxytocin level and marked progress in the cervical dilation. Thus, it can be assumed that when a water labour does not evolve according to the expected time frame $(2 \mathrm{hr})$ or even sooner, the beneficial effects of water have not taken place (as evidenced by a lack of uterine contractions). 18

It seems that maternal relaxation due to immersion in warm water favours greater elasticity of the pelvic tissues, reduces the painful sensation of 
Participants in the Water Birth Project (WBP), 2011 to 2014, Hospital de São Bernardo, Setúbal, Portugal.

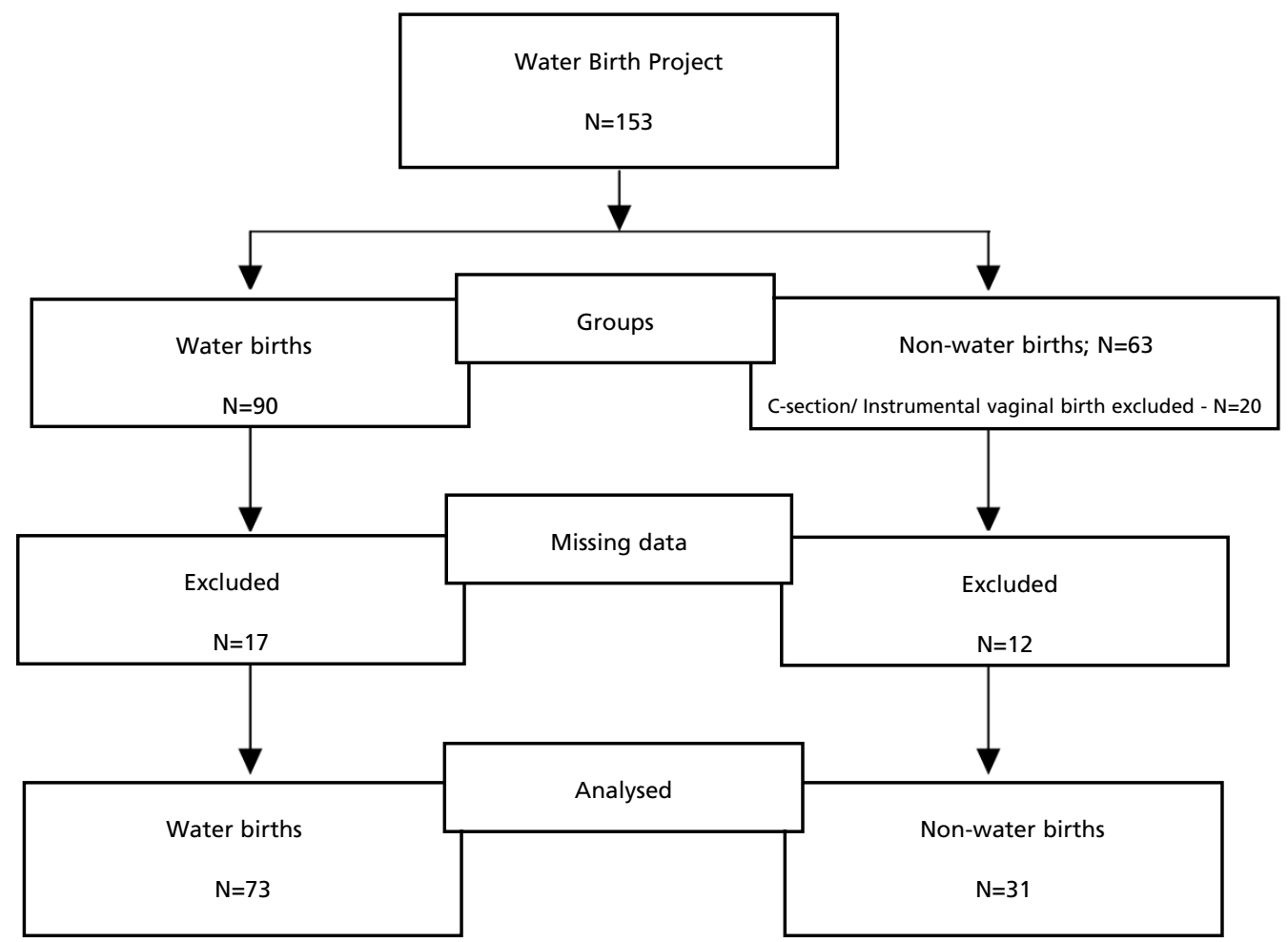

Table 1

Demographic and obstetric variables, perineal and neonatal outcomes of the participants. Water Birth Project (WBP), Hospital São Bernardo, Setúbal, Portugal, 2011-2014 ( $\mathrm{N}=104)$.

\begin{tabular}{lcc}
\hline Variables & N & \% \\
\hline Maternal age (years) & 32 & 30.8 \\
$<30$ & 51 & 49.0 \\
$30-35$ & 21 & 20.2 \\
$\geq 36$ & & \\
& & 15.4 \\
Gestational age (weeks+days) & 16 & 73.1 \\
$37+0$ to $38+6$ & 76 & 11.5 \\
$39+0$ to $40+6$ & 12 & - \\
$41+0$ to $41+6$ & 0 & \\
42 or more & & 64.4 \\
& & 35.6 \\
Parity & 67 & \\
Primiparous & 37 & 64.4 \\
Multiparous & & 26.0 \\
& & 8.7 \\
Delivery at term (obstetric history) & 67 & 0.9 \\
Never & 27 & \\
Once & 09 & \\
Twice & 01 & \\
Three times & & \\
\hline
\end{tabular}


Demographic and obstetric variables, perineal and neonatal outcomes of the participants. Water Birth Project (WBP), Hospital São Bernardo, Setúbal, Portugal, 2011-2014 (N = 104).

\begin{tabular}{lcc}
\hline Variables & $\mathbf{N}$ & $\%$ \\
\hline Length of labour (hr) & & 40.4 \\
$\leq 4$ & 42 & 38.5 \\
$5-8$ & 40 & 21.1 \\
$>8$ & 22 & 1.9 \\
Newborn weight (g) & & 93.3 \\
$<2.500$ & 02 & 4.8 \\
$\geq 2.500-4.000$ & 97 & 16.3 \\
$>4.000$ & 05 & 35.6 \\
Perineal outcome & & 28.8 \\
Intact perineum & & 5.8 \\
First-degree laceration & 17 & 13.5 \\
Second-degree laceration & 37 & \\
Third-degree laceration & 30 & 6 \\
Episiotomy & 14 & \\
\hline
\end{tabular}

\section{Table 2}

Proportion of women by type of childbirth (delivery in water or out of water), according to pregnancy characteristics, labour, and delivery. Water Birth Project (WBP), Hospital São Bernardo, Setúbal, Portugal, 2011-2014.

\begin{tabular}{|c|c|c|c|c|c|}
\hline \multirow[t]{2}{*}{ Variables } & \multicolumn{2}{|c|}{ Water birth } & \multicolumn{2}{|c|}{ Non-water birth } & \multirow[t]{2}{*}{$p^{*}$} \\
\hline & $\mathrm{n}$ & $\%$ & $\mathrm{n}$ & $\%$ & \\
\hline Maternal age (years) & & & & & 0.332 \\
\hline$<30$ & 23 & 31.5 & 09 & 20.0 & \\
\hline $30-35$ & 38 & 52.1 & 13 & 41.9 & \\
\hline$\geq 36$ & 12 & 16.4 & 09 & 29.1 & \\
\hline Gestational age (weeks+days) & & & & & 0.880 \\
\hline $37+0$ to $38+6$ & 12 & 16.4 & 04 & 12.9 & \\
\hline $39+0$ to $40+6$ & 53 & 72.6 & 23 & 74.2 & \\
\hline $41+0$ to $41+6$ & 08 & 11.0 & 04 & 12.9 & \\
\hline 42 or more & 0 & 0.0 & 0 & 0.0 & \\
\hline Number of pregnancies & & & & & 0.759 \\
\hline First pregnancy & 40 & 54.8 & 18 & 58.1 & \\
\hline Multiple pregnancy & 33 & 45.2 & 13 & 41.9 & \\
\hline Parity & & & & & 0.382 \\
\hline Primiparous & 49 & 67.1 & 18 & 58.1 & \\
\hline Multiparous & 24 & 32.9 & 13 & 41.9 & \\
\hline Length of labour (hr) & & & & & 0.001 \\
\hline$\leq 4$ & 36 & 49.3 & 06 & 19.4 & \\
\hline $5-8$ & 28 & 38.4 & 12 & 38.7 & \\
\hline$\geq 8$ & 09 & 12.3 & 13 & 41.9 & \\
\hline Directed pushing & & & & & $<0.001$ \\
\hline No & 53 & 72.6 & 10 & 32.3 & \\
\hline Yes & 20 & 27.4 & 21 & 67.7 & \\
\hline
\end{tabular}


Proportion of women by type of childbirth (delivery in water or out of water), according to pregnancy characteristics, labour, and delivery. Water Birth Project (WBP), Hospital São Bernardo, Setúbal, Portugal, 2011-2014.

\begin{tabular}{|c|c|c|c|c|c|}
\hline \multirow[t]{2}{*}{ Variables } & \multicolumn{2}{|c|}{ Water birth } & \multicolumn{2}{|c|}{ Non-water birth } & \multirow[t]{2}{*}{$p^{*}$} \\
\hline & $\mathrm{n}$ & $\%$ & $\mathrm{n}$ & $\%$ & \\
\hline Perineal outcomes & & & & & $<0.001$ \\
\hline Intact perineum & 12 & 16.4 & 05 & 16.1 & \\
\hline Episiotomy & 01 & 1.4 & 13 & 41.9 & \\
\hline First-degree laceration & 30 & 41.1 & 07 & 22.6 & \\
\hline Second-degree laceration & 30 & 41.1 & 0 & 0.0 & \\
\hline Third-degree laceration & 0 & 0.0 & 06 & 19.4 & \\
\hline Newborn weight (g) & & & & & 1.000 \\
\hline$<2.500$ & 02 & 2.7 & 0 & 0.0 & \\
\hline$\geq 2.500-4.000$ & 67 & 91.8 & 30 & 96.8 & \\
\hline$\geq 4.001$ & 04 & 5.5 & 01 & 3.2 & \\
\hline Total & 73 & 100.0 & 31 & 100.0 & \\
\hline
\end{tabular}

${ }^{*}$ Chi-square test and Fisher test.

contractions, and decreases the number of unnecessary obstetric interventions, such as forceps or suction cups, episiotomies, and the occurrence of severe perineal lacerations. 19,20 This decrease of severe perineal tears was point in the present study.

In 1993 a study21 showed that warm conductions through the skin and mucous tissue provoke peripheral vasodilation, causing an increase in venous return. These effects relieve pain because they reduce muscle spasms; however, the circulatory redistribution occurs to the detriment of other areas, such as the uterine muscle. Therefore, the author doubted if it was a good idea to keep labouring women immersed in water for a long period of time. ${ }^{21}$ For this reason, the protocol followed in the present study defined the maximum immersion time in two hours during labour and water birth.

The length of labour in the water births was significantly shorter when compared with the nonwater births (Table 2), but considering that this is a cross-sectional study, in which exposure and outcome are collected simultaneously, it is not possible to know whether the non-water labours were longer because they were more complicated, or whether they were more complicated because they were happening outside the water.

The same thinking applies to directed pushing, which occurred in non-water births to a greater degree than in water births, and the difference was statistically significant (Table 2). It is not possible to assume whether the directed pushing was requested because the labours happening outside the water were in fact more complicated, or if they turned out to be more complicated because they were happening outside the water. In a random study from the US, the directed pushing during the second stage of labour appeared to be a risk factor for perineal trauma in primiparous women. In a review on this same subject, no clear evidence was found about directed pushing during the second stage of labour associated with major perineal trauma. 22

On another systematic review about the effect of contraction control on birth, it was concluded that the length of the expulsive phase of labour in this case was significantly shorter than for women who used the Valsalva technique, but the neonatal results were not significantly different. On the other hand, women's urodynamic functions, measured 3 months after birth, were negatively affected by the contraction control technique. 23

Comparing second-degree lacerations with episiotomies, since they are equal in terms of tissue structures involved, primiparous women more often had perineal muscle rupture, and it was the same with more serious muscle lacerations, that is, the ones that affect the anal sphincter. It is important to say that, between all water birth participants, there were no records of perineal laceration affecting the anal sphincter (Table 3). There was a significant number of episiotomies in the group who had nonwater births (Table 3). In 13 of 31 (41.9\%) non-water births, an episiotomy was performed. Only 1 in 73 women who had a water birth underwent an episiotomy, although no justification record was found for this obstetric intervention.

We noted the absence of second-degree lacera- 
Proportion of women by perineal laceration degree, according to pregnancy characteristics, labour and delivery. Water Birth Project (WBP), Hospital São Bernardo, Setúbal, Portugal, 2011 2014.

\begin{tabular}{|c|c|c|c|c|c|c|c|c|c|c|c|}
\hline \multirow[t]{2}{*}{ Variables } & \multicolumn{2}{|c|}{ Intact perineum } & \multicolumn{2}{|c|}{ Episiotomy } & \multicolumn{2}{|c|}{$\begin{array}{l}\text { First-degree } \\
\text { laceration }\end{array}$} & \multicolumn{2}{|c|}{$\begin{array}{l}\text { Second-degree } \\
\text { laceration }\end{array}$} & \multicolumn{2}{|c|}{$\begin{array}{l}\text { Third-degree } \\
\text { laceration }\end{array}$} & \multirow[t]{2}{*}{$p^{*}$} \\
\hline & $\mathrm{n}$ & $\%$ & $\mathrm{n}$ & $\%$ & $\mathrm{n}$ & $\%$ & $\mathrm{n}$ & $\%$ & $\mathrm{n}$ & $\%$ & \\
\hline Maternal age (years) & & & & & & & & & & & 0.609 \\
\hline$<30$ & 05 & 29.4 & 03 & 21.4 & 13 & 35.1 & 10 & 33.3 & 01 & 16.7 & \\
\hline $30-35$ & 10 & 58.8 & 06 & 42.9 & 18 & 48.7 & 15 & 50.0 & 02 & 33.3 & \\
\hline$\geq 36$ & 02 & 11.8 & 05 & 35.7 & 06 & 16.2 & 05 & 16.7 & 03 & 50.0 & \\
\hline Gestational age (weeks+days) & & & & & & & & & & & 0.203 \\
\hline $37+0$ to $38+6$ & 04 & 23.5 & 01 & 7.1 & 04 & 10.8 & 06 & 20.0 & 01 & 16.7 & \\
\hline $39+0$ to $40+6$ & 13 & 76.5 & 12 & 85.8 & 30 & 81.1 & 18 & 60.0 & 03 & 50.0 & \\
\hline $41+0$ to $41+6$ & 00 & 0.0 & 01 & 7.1 & 03 & 8.1 & 06 & 20.0 & 02 & 33.3 & \\
\hline Number of pregnancies & & & & & & & & & & & 0.199 \\
\hline First pregnancy & 05 & 29.4 & 09 & 64.3 & 23 & 62.2 & 17 & 56.7 & 04 & 66.7 & \\
\hline Multiple pregnancy & 12 & 70.6 & 05 & 35.7 & 14 & 37.8 & 13 & 43.3 & 02 & 33.3 & \\
\hline Parity & & & & & & & & & & & 0.110 \\
\hline Primiparous & 06 & 35.3 & 10 & 71.4 & 25 & 67.6 & 22 & 73.3 & 04 & 66.7 & \\
\hline Multiparous & 11 & 64.7 & 04 & 28.6 & 12 & 32.4 & 08 & 26.7 & 02 & 33.3 & \\
\hline Length of labour ( $\mathrm{hr}$ ) & & & & & & & & & & & 0.003 \\
\hline$\leq 4$ & 07 & 41.2 & 01 & 7.1 & 15 & 40.5 & 19 & 63.3 & 0 & 0.0 & \\
\hline $5-8$ & 06 & 35.3 & 07 & 50.0 & 13 & 35.1 & 11 & 36.7 & 03 & 50.0 & \\
\hline$\geq 8$ & 04 & 23.5 & 06 & 42.9 & 09 & 24.3 & 0 & 0.0 & 03 & 50.0 & \\
\hline Directed pushing & & & & & & & & & & & 0.001 \\
\hline No & 14 & 82.3 & 04 & 28.6 & 21 & 56.8 & 23 & 76.7 & 01 & 16.7 & \\
\hline Yes & 03 & 17.7 & 10 & 71.4 & 16 & 43.2 & 07 & 23.3 & 05 & 83.3 & \\
\hline Delivery & & & & & & & & & & & $<0.001$ \\
\hline Water birth & 12 & 70.6 & 01 & 7.1 & 30 & 81.1 & 30 & 100.0 & 0 & 0.0 & \\
\hline Non-water birth & 05 & 29.4 & 13 & 92.9 & 07 & 18.9 & 0 & $0 . .0$ & 06 & 100.0 & \\
\hline Newborn weight (g) & & & & & & & & & & & 1.000 \\
\hline$<2.500$ & 0 & 0.0 & 0 & 0.0 & 01 & 2.7 & 01 & 3.3 & 0 & 0.0 & \\
\hline$\geq 2.500-4.000$ & 16 & 94.1 & 14 & 100.0 & 34 & 91.9 & 27 & 90.0 & 06 & 100.0 & \\
\hline$\geq 4.001$ & 01 & 5.9 & 0 & 0.0 & 02 & 5.4 & 02 & 6.7 & 0 & 0.0 & \\
\hline Total & 17 & 100.0 & 14 & 100.0 & 37 & 100.0 & 30 & 100.0 & 06 & 100.0 & \\
\hline
\end{tabular}

*Chi-square test and Fisher test. 
tions in women who had non-water births, whereas this group had a $41.9 \%$ rate of episiotomies. In an equally paradoxical study, pointing to the nonperformance of episiotomy as a risk factor for second-degree laceration, the authors analysed 489 births. 24 They identified $91 \%$ of women with some degree of laceration. All nulliparous women with spontaneous birth who gave birth without episiotomy were nine times more likely to have any degree of laceration, when compared with the ones who underwent an episiotomy. The authors concluded that the absence of episiotomy was the unique independent variable associated with seconddegree laceration. 24

In a review about this subject, when compared with any kind of spontaneous second-degree laceration, the episiotomy was shown to be a more serious injury, with major and more long-lasting complications. 25 Although equal with respect to level of tissue damage, episiotomies and second-degree lacerations are not mutual substitutes for one another. What is expected with episiotomies is not a reduction of risk of second-degree, but lower risk of worse lacerations to the perineal region, which can damage the anal sphincter.

In a study25 involving 1079 births, in which the births were assisted exclusively by midwife nurses, the perineal outcomes were different from those found in the present study, and contained $43.6 \%$ intact perineum, $31.9 \%$ first-degree lacerations, $10.3 \%$ second-degree lacerations, $12.9 \%$ mediolateral episiotomies, and $1.2 \%$ midline episiotomies. The study did not register any case of third-degree laceration, an outcome that is said to be avoided by the episiotomy's execution. 26

In the present study, what draws attention is the high number of spontaneous third-degree lacerations, those which affect the anal sphincter (19.4\%) in the non-water birth group. In a pioneer project of water birth in Singapore, ${ }^{26}$ which took place in a school hospital during 2010-2013, with 118 water births, the participants' outcomes were compared to the outcomes of an equal number of controls, women with the same characteristics of the cases and who gave birth at the same time. In both groups, there were no third- or fourth-degree lacerations, but the women from the control group underwent more episiotomies, $63.6 \%$ versus $0.85 \%(p<0.01) .27$

A question that should be discussed is the perineal laceration classification. There are plenty of individual variations on anatomic structures of the perineal-vulvar region, such as subcutaneous and muscular tissue depth, tonality, and the presence of local bleeding, which can complicate the diagnosis.
A laceration's form can also interfere with its classification, as well as the lack of tested and standardised equipment to reduce an evaluation's subjectivity.

The first degree-laceration rates were two times higher in the water deliveries compared with the non-water deliveries; this fact allows us to make some assumptions (Table 2). There is a tendency to minimise the perineal consequences when what is the birth modality being proposed is under analysis, when the objective is to show water birth as being better than the convectional type of birth. So, it can happen that some of the second-degree lacerations are classified as first degree, not because of bad intentions, but due to a bias. The most common occurrence is that minor lacerations, even when there is bleeding and tissue trauma, are classified as intact perineum, just because suturing was not necessary.

In a study about the diagnosis concordance among diverse groups of evaluators, all midwife nurses, there was a concordance between them in $72.7 \%$ of perineal lacerations. After some training, this concordance score was even lower (66.7\%) which can indicate the persistence of classification bias of the degree of laceration.28 In other study, using a perineal trauma evaluation instrument with 130 women who had a normal birth, half of the lacerations classified as first degree presented muscular damage. There was also a case of thirddegree laceration registered as second-degree laceration. 29

In a cross-sectional study, performed at a birth centre where the delivery care is provided by midwives, they evaluated perineal trauma in women who delivered in water compared with out-of-water delivery. The study found less morbidity and less perineal trauma in childbirth in water. 30

The search for sources to obtain better perineal results, with less impact on birth physiology, is an ideal to be followed. The water birth can be this differential, considering that the woman in the water is less exposed to manipulations and local examinations and, therefore, she feels less pain, and consequently, she will be more able to better command the velocity and rhythm of the expulsion of the foetus.

The water birth was significantly associated with lower rates of perineal trauma and shorter length of labour, as well as less directed pushing during the second stage of labour. In addition, there was an association with lower rates of episiotomy. Because this is a cross-sectional study, it is not possible to attribute causality for our findings. However, such small findings, like the absence of lacerations 
affecting the anal sphincter in water births, along with an almost one-fifth of non-water births with this type of laceration, speak about the water birth's protective factor to major perineal trauma. All findings seem to be leaning in favour of water birth. Prospective studies are necessary to analyse a possible causal relation between the water birth and its protective effect for perineal outcomes versus non-water births.

The retrospective collection in secondary data may present information bias, even if they were registered by the same team, in systematic records and developed especially for WBP. The size of the sample is a limitation, but the results are promising

\section{References}

1. WHO (World Health Organization). Care Normal Birth: a practical guide. Geneva: Department of Reproductive Health \& Research. WHO/FRH/MSM/96.24; 1996.

2. Enkin MW, Keirse MJNC, ReefrewMJ, Neilson JP. A guide to effective care in pregnancy and childbirth. In: The second stage of labour. 2 ed. Oxford: Oxford University Press; 1999. p. 226-35.

3. NICE (National Institute for Health and Care Excellence). Intrapartum care for healthy women and babies. Clinical guideline. Published: 3 December 2014. Nice.org.uk/guidance $/ \operatorname{cg} 190$

4. Landy HJ, Laughon SK, Bailit J, Kominiarek MA, Gonzalez-Quintero VH, Ramirez M, Haberman S, Hibbard J, Wilkins I, Branch DW, Burkman RT, Gregory K, Hoffman MK, Learman LA, Hatjis C, Vanveldhuisen PC, Reddy UM, Troendle J, Sun L, Zhang J; Consortium on Safe Labor. Characteristics associated with severe perineal and cervical lacerations during vaginal delivery. Obstet Gynecol. 2011; 117 (3): 627-35.

5. Aasheim V, Nilsen A, Reinar L, Lukasse M.Perineal techniques during the second stage of labour for reducing perineal trauma. Cochrane Database Syst Rev. 2017; 6: CD006672. doi:10.1002/14651858.CD006672.pub3

6. MousM, Muller AS, De Leeuw JW. Long-term effects of anal sphincter rupture during vaginal delivery: faecal incontinence and sexual complaints. BJOG. 2008; 115: 234-8.

7. Smith LA, Price N, Simonite V, Burns EE. Incidence of and risk factors for perineal trauma: a prospective observational study. BMC Pregnancy Childbirth. 2013; 13: 59.

8. Bulchandani S, Watts E, Sucharitha A, Yates D, Ismail K. Manual perineal support at the time of childbirth: a systematic review and meta-analysis. BJOG. 2015; 122 (9): 115765.

9. Lee N, Firmim M, Gao T, Kildea S.Perineal injury associated with hands on/hands poised and directed/undirected pushing: A retrospective cross-sectional study of non-operative vaginal births, 2011-2016. Int J Nurs Stud. 2018; 83: 11-17.

10. Scarabotto LB, Riesco MLG.Factors related to perineal and can subsidise and challenge other researchers to initiate their investigations of water birth.

\section{Authors' contribution}

Camargo JCS: responsible for the interview script and application of the same; data analysis and writing and discussion of the article. Ferreira FM, Osawa RH, Araújo Nm and Narchi N: data analysis and writing and discussion of the article. Varela V, Santos ME, Néné M, Grande C: critical review of the article. trauma in normal births in nulliparous. Rev Enferm USP. 2006; 40 (3): 389-95.

11. Cluett ER, Burns E, Cuthbert A. Immersion in water during labour and birth. Cochrane Database Syst Rev. 2018; (5): CD000111.

12. Nutter E, Meyer S, Shaw-Batista J, Marowitz A.Water birth: an integrative analysis of peer - reviewed literature. J Midwifery Women Health. 20014; 59 (3): 286-319.

13. Harper, B. Gentle Birth Choices. Healing Arts Press. Revised edition. 2005.

14. Odent M. Birth Under Water. Lancet. 1983; 2 (8365-66): 1476-77.

15. RCM (Royal College of Midwives). Immersion in Water for Labour and Birth. Evidence Based Guidelines for Midwifery-Led Care in Labour. 2012. [accessed 19 July 2018]. https://www.rcm.org.uk/sites/default/files/ Immersion \%20in\%20Water\%20\%20for\%20Labour\%20and \%20Birth_0.pdf

16. Portugal. Direção-Geral da Saúde. Programa Nacional para a Vigilância da Gravidez de Baixo Risco. Lisboa, 2015. [acesso em 15 Mai 2019]. Disponível em: $<$ https://www.dgs.pt/em-destaque/programa-nacional-paraa-vigilancia-da-gravidez-de-baixo-risco.aspx>.

17. Spong CY. Defining "term" pregnancy: recommendations from the defining "Term" Pregnancy Workgroup. JAMA. 2013; 309 (23): 2445-6.

18. Odent M. The Birthing Pool Test. Midwifery Today Int Midwife. 2015; Autumn; (115): 9-11.

19. Zanetti-Dallenbach RA, Tschudin S, Zhong XY, Holzgreve W, Lapaire O, Hosli I. Maternal and neonatal infections and obstetrical outcome in water birth. Eur J Obstet Gynecol Reprod Biol. 2007; 134 (1): 37-43.

20. Camargo JCS, Varela V, Ferreira FM, Pougy L, Ochiai AM, Santos ME, Grande MCLR. Waterbirth Project: São Bernardo Hospital Experience, Setúbal, Portugal. Women Birth. 2018; 31: e325-e333.

21. Zimmermann R, Huch A, Huch R.Water birth - is it safe? J Perinat Medicine. 1993; 21 (1): 5-11. 
22. Albers LL, Sedler KD, Bedrick EJ, Teaf D, Peralta P. Factors Related to Genital Tract Trauma in Normal Spontaneous Vaginal Births. Birth. 2006; 33 (2): 94-100.

23. Lemos A, Amorim MM, Dornelas de Andrade A, de Souza A, Cabral Filho JE, Correia JB.Pushing/bearing down methods for the second stage of labour. Cochrane Database Syst Rev. 2015; 3: CD009124.

24. Prins M, Boxem J, Lucas C, Hutton E.Effect of spontaneous pushing versus Valsalva. BJOG. 2011; 118 (6): 662-70

25. Mora-Hervás I, Sánchez E, Carmona F, Espuña-Pons, M. Perineal trauma in primiparous women with spontaneous vaginal delivery: episiotomy or second degree perineal tear? IJWHR. 2015; 3(2): 84-8.

26. Silva FM, de Oliveira SM, Bick D, Osava RH, Tuesta EF, Riesco ML. Risk factors for birth-related perineal trauma: a cross-sectional study in a birth centre. J Clin Nurs. 2012; 21: $2209-18$
27. Lim KMX, Tong PSY, Chong YS. A comparative study between the pioneer cohort of water births and conventional vaginal deliveries in an obstetrician led-unit in Singapore. Taiwan J Obstet Gynecol. 2016; 55 (3): 363-7.

28. Colacioppo PM, Riesco MLG, Colacioppo RC, Osava RH.Evaluation of bias in classification of perineal lacerations in vaginal delivery. Acta Paul Enferm. 2011; 24 (1): 61-6.

29. Metcalfe A, Tohill S, Williams A, Haldon V, Brown L, Henry L. A pragmatic tool for the measurement of perineal tears. Br J Midwifery. 2002; 10 (7): 412-7.

30. Dahlen HG, Dowling H, Tracy M, Schmied V, Tracy S Maternal and perinatal outcomes amongst low risk women giving birth in water compared to six birth positions on land. A descriptive cross sectional study in a birth centre over 12 years. Midwifery. 2013; 29 (7): 759-64.

Received on November 29, 2018

Final version presented on May 30, 2019

Approved on June 11, 2019 